\title{
KARAKTERISASI IKAN TERI ASIN (Stolephorus sp.) YANG DIPRODUKSI DI DESA WABURENSE, KECAMATAN MAWASANGKA, KABUPATEN BUTON TENGAH
}

Characterization of Salted Anchovy Produced in Waburense Area, Mawasangka District, Central Buton Regency

\author{
Taufik*, Kobajashi T. Isamu, Suwarjoyowirayatno \\ Jurusan Teknologi Hasil Perikanan, Fakultas Perikanan dan Ilmu Kelautan Universitas Halu Oleo, Kendari, \\ Sulawesi Tenggara, Indonesia \\ *Email korespondensi: taufik.upik015@gmail.com (Telp: +6285298248429) \\ Diterima: 5 Januari/ Disetujui 7 April 2021
}

Cara sitasi: Taufik, Isamu KT, Suwarjoyowirayatno. 2021. Karakterisasi Ikan Teri Asin (Stolephorus sp.) yang Diproduksi di Desa Waburense, Kecamatan Mawasangka, Kabupaten Buton Tengah. Jurnal Fish Protech. 4(1):80-85.

\section{ABSTRACT}

The aims of this study was to determine the proximate content (water content, ash, fat, protein), and salt content. Data analysis was used descriptive analysis to provide a general description of the data. Proximate Test Results on Salted anchovy water content ranged from $18.61 \%-19.68 \%$, salted anchovy ash content from $12.69 \%-14.26 \%$, protein content $37.37 \%-41.25 \%$, fat content from $1.05 \%-1.18 \%$ and salt content from $12.62 \%-13.42 \%$.

Keywords: Salted anchovy, proximate and salinity

\section{ABSTRAK}

Peneletian ini bertujuan untuk mengetahui kandungan proksimat (kadar air, kadar abu, kadar lemak, kadar protein), dan kadar garam. analisis data penelitian ini menggunakan analisis deskriptif untuk memberikan gambaran umum tentang data. Hasil uji proksimat pada kadar air ikan teri asin berkisar 18,61\%-19,68\%,kadar abu ikan teri asin berkisar 12,69\%-14,26\%, kadar protein ikan teri asin 37,37\%-41,25\%, kadar lemak ikan teri asin berkisar 1,05\%-1,18\% dan kadar garam berkisar antara $12,62 \%-13,42 \%$.

Kata kunci: Ikan teri asin, proksimat, kadar garam

\section{PENDAHULUAN}

Sumber daya ikan laut secara umum dapat dikelompokkan menjadi 3 bagian yaitu sumber daya ikan pelagis kecil, pelagis besar dan demersal. Sumber daya ikan pelagis kecil merupakan sumber daya perikanan yang berukuran kecil salah satunya yaitu ikan teri (Stolephorus sp). Sumber daya ikan tersebut cukup melimpah dan hasil tangkapannya dimanfaatkan oleh masyarakat sebagai ikan konsumsi. Menurut Direktorat Jenderal Perikanan Tangkap Jumlah tangkapan ikan teri di Indonesia pada tahun 2010 adalah 175.726 ton (dengan nilai produksi mencapai 2.160 milyar rupiah), sedangkan pada tahun 2014, produksi ikan teri meningkat menjadi 199.226 ton (Direktorat Jenderal Perikanan Tangkap, 2011).
Potensi jumlah sumber daya perikanan yang besar memerlukan pengembangan dan pengolahan lanjutan yang lebih terarah pada peningkatan kesejahteraan masyarakat. Upaya untuk meningkatkan kesejahteraan masyarakat dapat dilakukan dengan cara pengolahan hasil tangkapan ikan pelagis kecil seperti ikan teri yang biasanya dilakukan dengan proses penjemuran sehingga menghasilkan ikan teri kering. Oleh karena itu, kegiatan ini dilakukan dengan tujuan untuk meningkatkan kualitas produk ikan teri kering yang biasa dilakukan oleh masyarakat dan melakukan diversifikasi produk olahan berbahan dasar ikan teri 
untuk memberikan nilai tambah pada produk ikan teri tersebut (Maria, 2017)

Namun salah satu permasalahan yang dihadapi dalam proses pengasinan adalah belum diterapkan standar proses yang baku, sehingga kualitas produk ikan asin yang dihasilkan dapat berbeda-beda. Perbedaan tersebut dapat dipengaruhi oleh beberapa faktor diantaranya adalah tingkat kemurnian garam, ketebalan daging ikan, kesegaran ikan, temperatur ikan, dan konsentrasi larutan garam yang digunakan Selain itu, beberapa permasalahan yang sering dijumpai dalam proses pengeringan adalah lama waktu proses pengeringan yang tidak seragam (Adawiyah, 2008). Untuk peningkatan mutu dan pengembangan produk hasil perikanan tradisional yang berkualitas dan terjamin keamanannya perlu perhatian dengan cara pengawasan dan penanganan hasil selama proses pengolahan hingga ke konsumen. Oleh karena itu perlu dilakukan pengamatan dan penelitian dengan karakterisasi ikan teri asin yang diproduksi di Desa Waburense Kecamatan Mawasangka Kabupaten Buton Tengah.

\section{METODE PENELITIAN}

\section{Bahan}

Bahan yang digunakan terdiri dari dua jenis. Bahan utama yaitu ikan teri yang diproduksi dari di Desa Waburense Kecamatan Mawasangka Kabupaten Buton Tengah. Bahan untuk uji kimia Prosedur Penelitian

Pada penelitian ini pengambilan sampel Ikan Teri dilakukan secara acak di beberapa produsen di Desa Waburense. Proses pengambilan sampel di Desa Waburense Kecamatan Mawasangka Kabupaten Buton Tengah. Yaitu pemilihan lokasi tersebut karena produk ikan teri asin masih banyak diperjual belikan. Pengambilan sampel sebanyak 500 gr tiap lokasi. dalam proses pemasaran ikan teri asin, pedagang menjual bahan baku dalam bentuk pengemasan. adalah aquades, alkohol $80 \%, \mathrm{NaOH}, \mathrm{H}_{2} \mathrm{SO}_{4}, \mathrm{NaCl}$, heksan, dan larutan standar protein. Bahan uji mikroba yaitu aquades, $\mathrm{HNO}_{3}, \mathrm{HClO}_{4}$,serbuk $\mathrm{Ca}\left(\mathrm{NO}_{3}\right)_{2}$, $\mathrm{NaNO}_{3}$, dan $\mathrm{PO}_{3}$ - , asam nitrat $\left(\mathrm{HNO}_{3}\right)$ pekat, dan asam klorida $(\mathrm{HCl})$ pekat.

Parameter uji dari tiap lokasi dilakukan pengujian kandungan kimia (proksimat) yang meliputi : Pengujian kimia (analisis kadar air, abu, lemak, protein dan karbohidrat).

\section{Analisis Data}

Data yang diperoleh dianalisis menggunakan analisis deskriptif. Analisis deskriptif digunakan untuk memberikan gambaran umum tentang data yang telah diperoleh.

\section{Analisis Kandungan Kimia}

\section{HASIL DAN PEMBAHASAN}

Hasil rerata nilai uji kadar air, kadar abu, kadar protein, kadar lemak, kadar garam ikan teri asin yang diperdagangkan di Desa Waburense Kecamatan Mawasangka di Kabupaten Buton Tengah dapat dilihat pada

Tabel 1. Rerata nilai kandungan proksimat dan kadar garam ikan teri asin

\begin{tabular}{lllllll}
\hline Pengujian & P1 & P2 & P3 & P4 & SNI & No. \\
\hline Kadar air (\%) & 18,61 & 19,68 & 19,42 & 19,39 & 40 & $01-2354.2-2006$ \\
Kadar abu (\%) & 14,26 & 12,47 & 13,03 & 12,69 & 0,3 & $01-2354.1-2010$ \\
Kadar protein (\%) & 41,25 & 34,37 & 39,17 & 37,37 & - & - \\
Kadar lemak (\%) & 1,06 & 1,05 & 1,18 & 1,08 & - & - \\
Kadar garam (\%) & 12,62 & 13,10 & 13,15 & 13,42 & 15 & $01-2359-1991$ \\
\hline
\end{tabular}

Ket: P1= Produsen 1, P2= Produsen 2, P3= Produsen 3, P4= Produsen 4

$\mathrm{SNI}=$ Standar Nasional Indonesia 


\section{Pembahasan}

\section{a. Kadar air}

Hasil uji proksimat terhadap kadar ikan teri asin yang dipasarkan di Desa Waburense Kecamatan Mawasangka Kabupaten Buton Tengah (Tabel 1) menunjukkan nilai tertinggi terdapat pada P2 dengan nilai $25,84 \%$ dan nilai terendah pada P1 dengan nilai $18,61 \%$. Proses pengeringan membuat kandungan air ikan teri asin turun menjadi 19,68\%, sedangkan proses pengeringan ikan teri asin membuat kadar air turun menjadi $18,61 \%$. Nilai tersebut lebih rendah dibandingkan hasil penelitian Ali et al. (2018) tentang proses pengolahan ikan teri dalam mendukung konsep zero waste melaporkan bahwa kandungan kadar air mencapai 42,25\%.

Berdasarkan hasil penelitian sebelumnya menurut Winarno (1993) pengeringan adalah suatu cara untuk mengeluarkan atau menghilangkan sebagian air yang terkandung dalam suatu bahan dengan cara menguapkan air melalui penggunaan energi dan pengeringan akan bertambah baik dan cepat apabila telah dilakukan proses penjemuran sebelumnya. Kadar air teri asin kering yang dihasilkan masih memenuhi standar yang ditetapkan, standar maksimun kadar air teri asin kering berdasarkan (SNI No.01-2708-1992) yaitu 35\%. Kadar air teri asin kering yang dihasilkan jauh menurun dibandingkan kadar air teri segar yaitu $80 \%$. Hal ini disebabkan faktor pengeringan dan penggaraman. Pengeringan atau penjemuran dengan sinar matahari akan menguapkan sebagian besar air yang terkandung dalam ikan teri segar.

\section{b. Kadar abu}

Sebagian besar bahan makanan, yaitu sekitar 96\% terdiri dari bahan organik dan air sisanya terdiri dari unsur-unsur mineral. Unsur mineral juga dikenal sebagai zat organik atau kadar abu. Berdasarkan Tabel 1, hasil analisis kadar abu tertinggi terdapat pada P1 dengan nilai $14,26 \%$ dan nilai terendah pada P2 dengan nilai $12,47 \%$. Hasil penelitian ini diduga karena semakin lama waktu pengeringan maka kadar abu semakin meningkat. Asrawaty (2011), peningkatan kadar abu ini terjadi karena semakin lama waktu dan semakin tinggi suhu pengeringan maka akan semakin banyak air yang teruapkan dari bahan yang dikeringkan. Sesuai dengan pernyataan Sudarmadji et al. (1997), bahwa kadar abu tergantung pada jenis bahan, waktu dan suhu yang digunakan saat pengeringan. Jika bahan yang diolah melalui proses pengeringan maka lama waktu dan semakin tinggi suhu pengeringan akan meningkatkan kadar abu karena air yang keluar dari dalam bahan semakin besar. Nilai tersebut lebih tinggi dibandingkan penelitian Hasil penelitian Ali et al. (2018) tentang proses pengolahan ikan teri dan pemanfaatan limbahnya bahwa kandungan $6,62 \%$. SNI kadar abu dengan nilai berkisar berkisar minimal 0,3\%. Hasil penelitian ini menunjukan telah melebihi standar yang ditentukan. Menurut penelitian sebelumnya Ruslan et al., (2019), kadar abu yang diperoleh berkisar 1,01$1,83 \%$.

\section{c. Kadar protein}

Hasil uji proksimat terhadap kadar protein ikan teri (Tabel 1) menunjukkan nilai tertinggi terdapat pada P1 dengan nilai $41,25 \%$ sedangkan nilai terendah pada P2 dengan nilai $34,37 \%$. Hal ini diduga karena dengan semakin lama waktu dan tingginya suhu pengeringan maka akan meningkat kadar protein dari ikan teri asin. Sejalan dengan pernyataan Adawyah (2007), kadar air yang mengalami penurunan akan mengakibatkan kandungan protein didalam bahan mengalami peningkatan. Penggunaan panas dalam pengolahan bahan pangan dapat menurunkan persentase kadar air yang mengakibatkan persentase kadar protein meningkat. Semakin kering suatu bahan maka semakin tinggi kadar proteinnya. Hal ini dikarenakan dengan semakin lama waktu dan tingginya suhu pengeringan maka akan meningkat kadar protein dari ikan teri asin. Kadar protein semakin menurun dengan semakin lamanya perendaman atau perebusan dalam larutan garam. Hal ini diduga semakin lama waktu perendaman atau perebusan akan membuat protein akan semakin terdenaturasi. Disamping itu menurut Wahjuni et al. (2001), menyatakan semakin lama ikan teri bersentuhan dengan larutan garam maka semakin besar terjadi penurunan kadar protein. 
Berdasarkan hasil penelitian sebelumnya kadar protein menurut Wahjuni et al. (2001) menyatakan, kadar protein diuji dengan metoda macro kjeldahl (SNI 01-2354.4-2006) bahwa kandungan protein tertinggi $(21,43 \%)$ diperoleh pada perlakuan perendaman dalam larutan garam $5 \%$ suhu $100 \mathrm{C}$ selama 1 menit, Sedangkan kadar protein terendah $(18,42 \%)$ diperoleh pada perlakuan perebusan dalam larutan garam $5 \%$ suhu $100^{\circ} \mathrm{C}$. Selama 15 menit dan kadar protein semakin menurun dengan semakin lamanya perendaman/perebusan dalam larutan garam. Hal ini diduga semakin lama waktu perendaman/perebusan akan membuat protein akan semakin terdenaturasi. Disamping itu semakin lama ikan teri bersentuhan dengan larutan garam maka semakin besar terjadi penurunan kadar protein .

\section{d. Kadar lemak}

Tabel 1 menunjukkan nilai rerata tertinggi terdapat pada P3 dengan nilai 1,18\% sedangkan nilai terendah pada P2 dengan nilai $1,05 \%$. Tingginya nilai kadar lemak ini terus berlangsung dengan semakin lamanya waktu yang digunakan selama proses pegeringan. Hal ini karena semakin lama waktu pengeringan maka kadar abu yang terdapat pada ikan teri asin semakin meningkat dan berbanding terbalik dengan nilai kadar air yang semakin menunjukkan penurunan seiring dengan semakin tinggi suhu dan waktu yang digunakan selama proses pengeringan. Sejalan dengan penelitian Yuniarti (2007), yang menyatakan bahwa dengan lamanya waktu dan tinggi suhu yang digunakan pada proses pengeringan akan menyebabkan kandungan lemak yang ada pada bahan juga semakin meningkat dan kandungan air yang semakin menurun. Hasil penelitian ini lebih rendah dari Yusriana et al. (2010) bahwa kandungan kadar lemak ikan teri asin kering 1,39\%.

Berdasarkan hasil penelitian Yuniarti (2007), kadar lemak diukur secara gravimetri (SNI 01- 2354.32006) hasil analisis pengaruh perlakuan terhadap kadar lemak teri asin kering dapat dilihat pada kadar lemak dari teri asin kering berkisar antara 1,20 $1,69 \%$ dengan kadar lemak rata rata 1,39\% dan kadar lemak tertinggi $1,69 \%$ diperoleh pada perlakuan perendaman dalam larutan garam $5 \%$ suhu $100^{\circ} \mathrm{C}$ selama 1 menit. Sedangkan kadar lemak terendah diperoleh pada perlakuan perebusan dalam larutan garam $5 \%$ suhu $100^{\circ} \mathrm{C}$ selama 15 menit. Semakin lama waktu perendaman/perebusan dalam larutan garam juga menurunkan kadar lemak teri asin kering yang dihasilkan. Hal ini diduga terjadinya degradasi lemak menjadi senyawa peroksida dan menguapnya sejumlah senyawa seperti aldehid dan keton selama perendaman/perebusan yang dapat menurunkan kadar lemak teri asin kering.

\section{e. Kadar garam}

Hasil uji terhadap kadar garam ikan teri asin (Tabel 1) menunjukkan nilai tertinggi terdapat pada P4 dengan nilai $13,42 \%$ sedangkan nilai terendah pada P1 dengan nilai $12,62 \%$. Jumlah kadar garam yang bervariasi tersebut diduga disebabkan oleh bervariasinya proses penggaraman dan pemberian garam sebanyak $3 \mathrm{~kg}$, pada saat pengolahan ikan teri asin akan melakukan proses penjemuran bebas dari naungan dengan tujuan agar sinar matahari dapat digunakan seluruhnya. Proses penjemuran digunakan dengan alat jaring, aktivitas penjemuran yang bertujuan untuk mengeringkan ikan ini harus dengan proses yang dilakukan 1-2 kali setiap harinya.

Kandungan kadar garam ini sudah memenuhi kisaran kadar garam yang disyaratkan SNI yaitu pada kisaran maksimal $15 \%$. Ikan teri yang layak untuk dikonsumsi dalam penelitian ini. Menurut penelitian sebelumnya, Fahmi et al. (2014) Kadar garam ikan teri nasi setengah kering tercatat $4,63 \%$ dan $5,53 \%$ sehingga dalam penelitian dari lebih tinggi di bandingkan penelitian sebelumnya.

\section{KESIMPULAN}

Berdasarkan hasil dan pembahasan, maka dapat disimpulkan sebagai berikut :

1. Hasil uji proksimat kadar air 18,61 $19.38 \%$, kadar abu $12,47-14,26 \%$, kadar protein $34,37-41,25 \%$, dan kadar lemak 1,05-1,18\%.

2. Hasil uji kadar garam didapatkan dengan nilai $12,62-13,42 \%$. 


\section{DAFTAR PUSTAKA}

Adawiyah, R. 2008. Pengolahan dan Pengawetan Ikan. PT Bumi Aksara. Jakrta.

Ali. 2018. Proses Pengolahan Ikan Teri (Stolephorus Sp.)Dan Pemanfaatan Limbahnya Sebagai Bahan Baku Pakan Ikan Dalam Mendukung Konsep Zero Waste. Jurnal Perikanan (2018) Volume 8. No. 1: 47-54.

Atmarita, Mahmud, Mien, K., (2005). Daftar Komposisi Bahan Makanan (DKBM). Malang: Sagung Seto.

Astawan, M. 2004. Kiat Menjaga Tubuh Tetap Sehat. Solo: Tiga Serangkai

Astrawaty. 2008. Sehat dengan Hidangan Hewani. Jakarta: Penebar Swadaya.

Asrawaty. 2011. Pengaruh suhu dan lama pengeringan terhadap mutu tepung pandan. Jurnal KIAT edisi juni. Universitas Alkhairaat. Palu.

Burhanuddin.2008. Ikhtiologi Ikan dan Aspek Kehidupannya. Yayasan Citra Emulsi. Makassar.

Csirke, J. 1988. Small Shoalding Fish Stocks. In J.A Gulland, ed. Fish Population Dyamic, 2nd John Willy and Sons, Chechester. 271-302.

Direktorat Jendral Perikanan Tangkap, 2011. Direktorat Sumberdaya Ikan. Direktorat

Perikanan Tangkap, Kementrian Kelautan dan Perikanan Republik Indonesia. Jakarta (ID).

De Bruin, G.H.P., B.C. Russel, and A. Bogusch. 1994. The Marine Fishery Resources of Sri Lanka. FAO Species Identification Field Guide for Fishery Purpose. Rome. M43. ISBN 92-5-103293, 400 pp.

Fahmi, A.S., W. F. Ma,ruf dan T. Surti. 2014. Laju Oksidasi Lemak dan Mutu Organoleptik Ikan Teri Nasi Kering (Stolephorus sp) Selama Penyimpanan Dingin. PENA Jurnal IImu Pengetahuan dan Teknologi, 27(1): 65-77

Gawaksa, Harpa P. 2014. Keanekaragaman Ikan Hasil Tangkapan. http://faktaharpa.blogspot.co.id. (24 Mei 2017).

Huss H.H. 1994. Assurance aof Sea Food Quality. FAO Fisheries Technical Paper. 334. Rome. M-40 ISBN 92-5-103446-X, 169 pp.

Huss H.H. 1995. Quality and Quality changes in Fresh Fish. FAO Fisheries Technical Paper.
338. Rome. M-47 ISBN 92-5-103507-5, 195 $\mathrm{pp}$.

Jasman, T. 2004. Bundes (Danish Seine) dan Dampaknya Terhadap Kelestarian Stok Ikan Diperairan Kota Tegal. Tesis. Universitas Diponegoro. Semarang.

Departemen Perindustrian. 1982. Pembuatan Ikan Asin. Balai Desa Penelitian dan Pengembangan Industri Hasil Perikanan. Publikasi No.4.

Kristina M, 2017. Peningkatan Kualitas Ikan Teri kering Di desa Sathean, Kecamatan Kei Kecil, Kabupaten Maluku Tenggara. Program Studi Teknologi Hasil Perikanan, Politeknik Perikanan Negeri Tual, Jalan Raya. Jurnal Pengabdian Kepada Masyakarat. Vol 3 (2): 150-156

Lasimpala, R. (2014). Uji Mutu Ikan Teri Kering pada Lama Pengeringan Berbeda (Thesis). Universitas Negeri Gorontalo, Gorontalo. Retrieved

Lambongadil, G,P., Reo, A.R \& Onibala, H. 2013. Studi Mutu Produk Ikan Japuh (Dussumieria acuta C.V.) Asap Kering Industri Rumah Tangga Di Desa Tumpaan

Baru Kecamatan Tumpaan. Fakultas Perikanan dan IImu Kelautan.

Universitas Samratulangi. Sulawesi Utara. Manado. Jurnal Me inologi Hasil Perikanan. 1(2): 12- , u.

Mahmud, (1990). Kadar Protein dan Ca Pada Ikan Teri Asin Hasil Pengasinan Dengan Abu Pelapah Kelapa. Muhammadiyah Surakarta. 2012

Maria, 2017. Peningkatan Kualitas Ikan Teri Kering di

Desa Sathean, Kecamatan Kei Kecil, Kabupaten Maluku Tenggara. Program Studi Teknologi Hasil Perikanan, Politeknik Perikanan Negeri Tual, Jalan Raya LanggurSathean Km.6, November 2017, Vol 3 (2): 150-156

Sudarmadji, S., B. Haryono, dan Suhardi. 1997. Prosedur Analisis untuk Bahan Makanan dan Pertanian. Liberty. Yogyakarta.

Winarno, F.G. 1993. Pangan: Gizi, Teknologi dan Konsumen. Gramedia, Jakarta.

Yuniarti, N., D. Syamssuwida dan A. Aminah. 2007.

Pengaruh penurunan kadar air terhadap 
perubahan fisiologi dan kandungan biokimia benih eboni (Diospyros celebica Bahk.). Jurnal Penelitian Hutan Tanaman edisi agustus Vol.
5 No. 3 Hal. 191 - 198. Balai Pembenihan. Teknologi Pembenihan Bogor. Bogor. 